\title{
Medievalista
}

Online

$8 \mid 2010$

Número 8

\section{O Mundo do Fantástico na Arte Românica e Gótica em Portugal}

Tese de Mestrado em História da Arte, apresentada à Faculdade de Ciências Sociais e Humanas da Universidade Nova de Lisboa em Julho de 2007. Orientação do Prof. Doutor José Custodio Vieira da Silva.

\section{Marisa Costa Marques}

\section{(2) OpenEdition}

1 Journals

\section{Edição electrónica}

URL: http://journals.openedition.org/medievalista/481

DOI: 10.4000/medievalista.481

ISSN: 1646-740X

\section{Editora}

Instituto de Estudos Medievais - FCSH-UNL

Refêrencia eletrónica

Marisa Costa Marques, "O Mundo do Fantástico na Arte Românica e Gótica em Portugal »,

Medievalista [Online], 8| 2010, posto online no dia 01 dezembro 2010, consultado o 15 setembro 2020. URL : http://journals.openedition.org/medievalista/481 
Titulo: Apresentação de Tese

O Mundo do Fantástico na Arte Românica e Gótica em Portugal.

Tese de Mestrado em História da Arte, apresentada à Faculdade de Ciências Sociais e Humanas da Universidade Nova de Lisboa em Julho de 2007.

Orientação do Prof. Doutor José Custodio Vieira da Silva.

$\frac{8}{2}$ Autor(es): Marisa Costa Marques

Enquadramento Institucional:

Contacto: costa.misc@gmail.com

Fonte: Medievalista [Em linha]. №8, (Julho 2010). Direc. José Mattoso. Lisboa: IEM.

Disponível em: http://www2.fcsh.unl.pt/iem/medievalista/

ISSN: $1646-740 \mathrm{X}$ 


\section{Apresentação de Tese}

\section{O Mundo do Fantástico na Arte Românica e Gótica em Portugal.}

Tese de Mestrado em História da Arte, apresentada à Faculdade de Ciências Sociais e Humanas da Universidade Nova de Lisboa em Julho de 2007. Orientação do Prof. Doutor José Custodio Vieira da Silva

\section{Marisa Costa Marques}

O tema principal deste estudo foi fundamentado sobretudo no imaginário do Homem medieval em Portugal.

Os bestiários configuram-se como documentos primordiais que influenciaram fortemente a sensibilidade e espiritualidade dos artistas desta época. A sua visão poética e moralizante do mundo, reflectiu-se nas alegorias e simbolismos das artes medievais. Os animais e criaturas monstruosas ou híbridas serão porventura o motivo escultórico que mais curiosidade desperta em nós e que mais efeito de intimidação provocaria na mentalidade da sociedade da Idade Média.

Tentámos no entanto interpretar as simbologias inerentes aos monstros e seres híbridos presentes em muitos capitéis e portais das nossas igrejas.

Porém era primordial começar por procurar definir alguns conceitos essenciais à compreensão dessas criaturas imaginárias, assim sendo começamos pelo Mito, depois a Lenda, seguida da Fábula e finalmente o Conto.

De definição complexa, o Mito é essencialmente narrativa de uma criação, que nos conta de que modo, algo até então inexistente, passou a existir, com interveniência sobrenatural. Sujeitos a várias classificações, os mitos influenciaram as artes em geral, muitas vezes propagados através da escrita. Mito e Cristianismo ocupam posições antagónicas, no entanto o segundo absorveu elementos do primeiro. As Sagradas Escrituras referem figuras mitológicas com a "Árvore da Vida" ou o "Dragão". Na Idade Média surgem vários exemplos do pensamento mítico, como por exemplo: o Mito do Santo Graal, o Mito do Vampirismo, ou o Mito das Amazonas. 
O Mito insere-se no sistema de crenças de uma sociedade e é um factor essencial da civilização humana, com os seus símbolos e signos. Possui uma lógica baseada no imaginário humano e reflecte a perplexidade e ansiedade do homem, na busca de explicação para a sua própria existência.

Muitas vezes confundida com o Mito, a Lenda é uma forma de narrativa muito ancestral que relata acontecimentos ocorridos em determinada época e local, e em que o maravilhoso e imaginário se sobrepõem ao histórico e verdadeiro. Na sua maioria, anónimas e preservadas pela transmissão oral, cujos protagonistas são pessoas, animais e criaturas com poderes sobrenaturais, as lendas misturam o fantástico com o real e vãose modificando consoante o local e a época.

Tal como a Lenda, a Fábula tem sempre um objectivo pedagógico, não passando de um pequeno conto, protagonizado por animais e reflecte sempre uma lição moral. As personagens têm acções semelhantes às humanas e fazem sempre uma sátira aos vícios e costumes. As Fábulas mais antigas que se conhecem são atribuídas a Esopo.

Por sua vez o Conto também possui um cariz fabuloso e fantástico, inspirado na mitologia, transmitido oralmente através de gerações. O Conto distingue-se, na literatura, pelo tamanho e estrutura. Geralmente tem apenas uma personagem principal. No seu enredo surge muitas vezes a magia, o maravilhoso, o herói que supera duras provas, numa espécie de ritual iniciático.

Mas tornou-se também para nós primordial tentar definir as criaturas monstruosas ou híbridas. Esses seres fabulosos referidos nos bestiários, provenientes de fértil imaginação, mas pouco questionados. Criaturas insólitas reveladas pelos viajantes, que encantaram o imaginário popular. O animal monstruoso foi quase sempre conotado com o Mal. Por seu lado o ser Híbrido não era menos assustador. Monstros e Híbridos integraram-se nas artes quase sempre com um sentido alegórico.

Contudo, para podermos tentar interpretar e atribuir algum significado às esculturas por nós analisadas, tivemos de ter em conta ainda outros conceitos como a Arte, a qual se insere num contexto cultural, local, temporal, histórico, dependendo também da sensibilidade e imaginação do artista; a Estética, que define o gosto de cada pessoa, estuda o Belo, as funções da Arte, a qualidade da obra, o processo da sua criação e a sua aceitação pelo público e também como não poderia deixar de ser, o Belo, identificado 
na época, com o Bem, o espiritual, o divino. No entanto o caminho para o Belo é bastante complexo.

Abordámos ainda, neste estudo, a temática das influências sofridas pela Arte Medieval europeia, a qual muito ficou a dever a outros povos e culturas tais como a Arte Bárbara, a Arte Bizantina, a Arte Islâmica, a Arte Carolíngia e a Arte Greco-Romana.

As religiões, rituais e costumes destes períodos, as suas manifestações artísticas em junção com a metamorfose estética operada pelo Cristianismo marcaram indelevelmente a arte europeia da Idade Média.

Nos séculos XI e XII o Românico, que em Portugal se estenderá até à primeira metade do século XIII, predominará na Europa Ocidental, com a sua exuberância escultórica, trazendo uma profusão ornamental de seres imaginários.

Em Portugal a escultura românica chegou pelos monges de Cluny e estendeu-se do Minho ao Alentejo, ela invadirá, tendo como lugar de eleição tímpanos, portais, arcadas, frisos, arquivoltas e capitéis, embora por vezes sem exuberância, em alguns programas iconográficos presentes noutras regiões.

E se no Românico a escultura adapta-se ao suporte arquitectónico, daí por vezes as suas desproporções, já no Gótico vai adquirir algum movimento, perspectiva e volume.

A iconografia do Românico converteu criaturas imaginárias em símbolos de virtudes e vícios. Apesar de focalizada em fins pedagógicos pela Igreja conteve também o maravilhoso e o misterioso.

$\mathrm{Na}$ catedral gótica a escultura adquire naturalidade, expressividade. O espaço é ocupado de forma mais clara e ordenada.

O período Gótico trouxe uma evolução na interpretação da natureza e também do papel do artista. O Gótico libertará o escultor dos limites arquitectónicos, contrapondo à rigidez anterior o movimento e expressividade.

Apesar das figuras fantásticas e híbridas terem recebido a nossa particular atenção, também nos detivemos na simbologia da Árvore da Vida, uma vez que ela surge frequentemente ladeada por animais míticos (um dragão e um grifo ou dois dragões). 
ÁRVORE DA VIDA - Com origem no Livro do Génesis, surge também no Livro do Apocalipse e está associada à cruz de Cristo.

Temos representações da Árvore da Vida em várias igrejas, das quais destacamos a Igreja de São Cristóvão de Rio Mau (Figura I) e a Capela de Nossa senhora da Orada (Figura II).

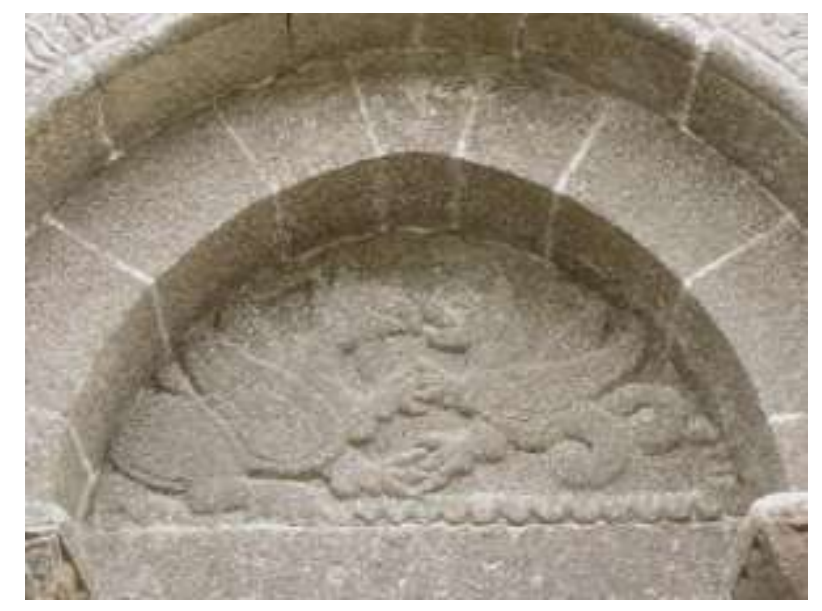

Figura I - Tímpano do Portal Norte

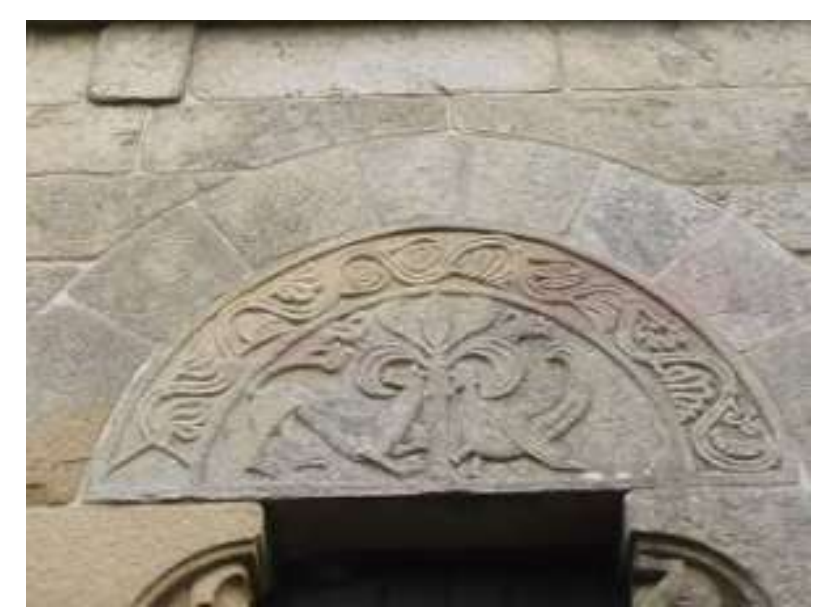

Figura II - Tímpano do Portal Norte da Capela de Nossa Senhora da Orada

CENTAUROS - É uma combinação ancestral do homem com o animal (cavalo). Criaturas selvagens e guerreiras combinavam o instinto animal com a sabedoria humana, simbolizam a união do irracional com o racional.

Podemos encontrar um centauro na Igreja de S. Cristóvão de Rio Mau (Figura III). 


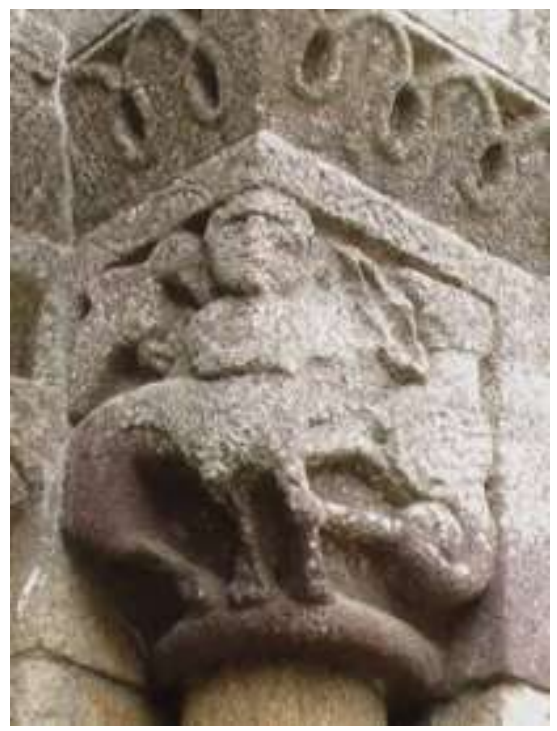

Figura III - Capitel do Portal Norte da Igreja de S. Cristóvão de Rio Mau

DRAGÕES - São criaturas misteriosas e fascinantes, presentes em variadas versões da luta do Bem com o Mal, que protagonizaram muitas lendas e mitos, fazendo parte do folclore de inúmeras regiões, os dragões foram os adversários ideais dos heróis, algumas vezes conotados com o Bem mas na maioria símbolos do Mal.

Animais fantásticos comuns em todas as mitologias e também na iconografia do Cristianismo. A sua imagem foi frequentemente adaptada na heráldica.

Existem vários exemplares de dragões nos capitéis e tímpanos das nossas igrejas, sendo as mais notáveis no Convento de Nossa Senhora da Conceição (Figura IV); na Igreja Matriz da Golegã (Figura V) e no Palácio de D. Manuel (Figura VI).
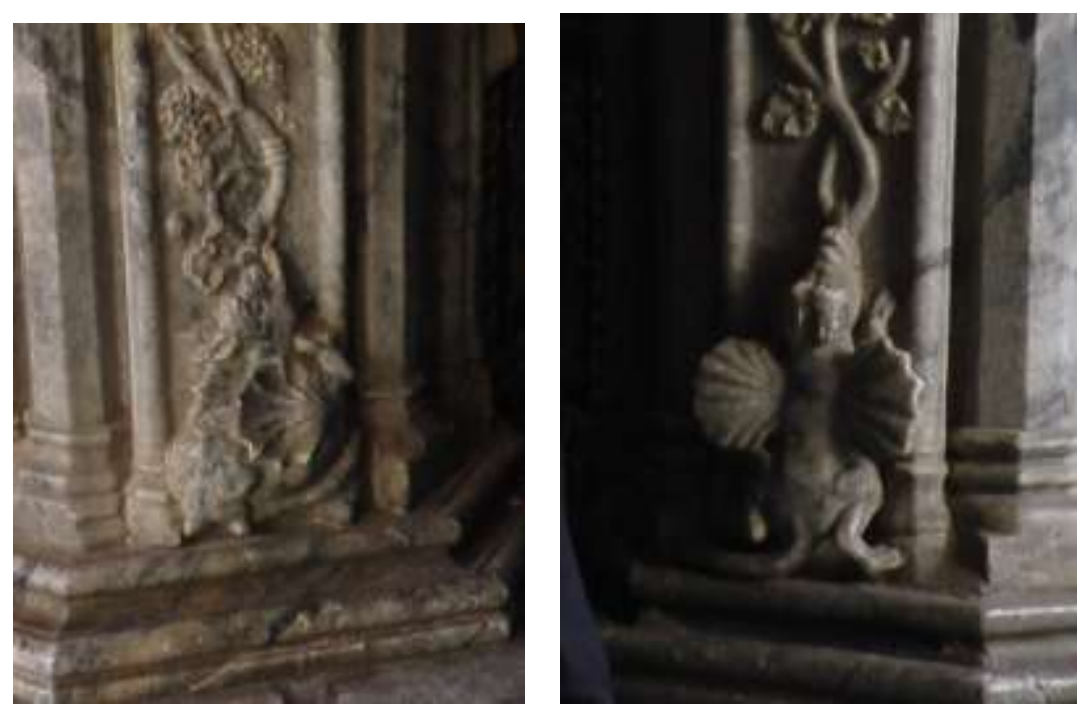

Figura IV - Portal da Sala do Capítulo do Convento de Nossa Senhora da Conceição

Medievalísta online No 8| Julho - Dezembro 2010 ๑ IEM - Instituto de Estudos Medievais 6 www2.fcsh.unl.pt/iem/medievalista 


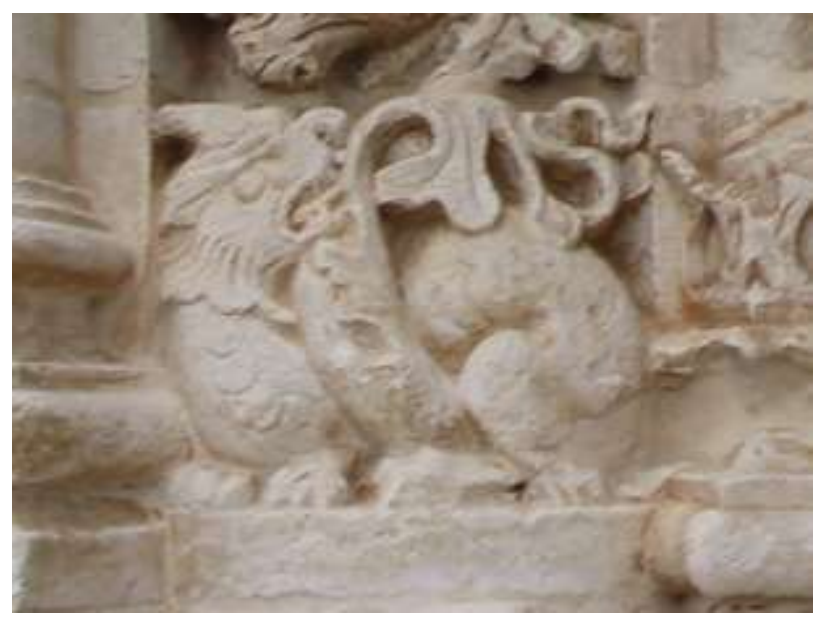

Figura V - Portal Principal da Igreja Matriz da Golegã

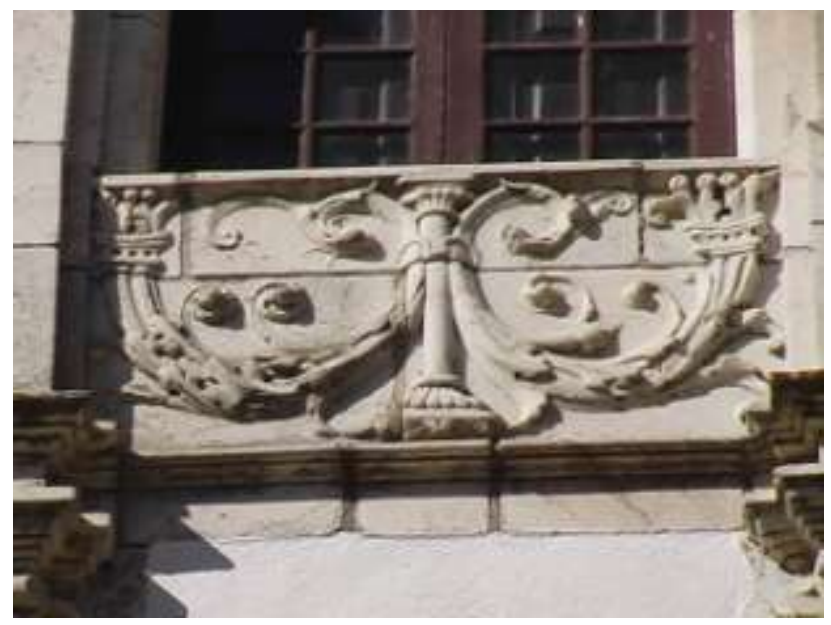

Figura VI - Janela do Palácio de D. Manuel

GRIFOS - São considerados criaturas híbridas, uma estranha combinação do corpo de um leão com asas de águia, que vigiavam os locais sagrados, eram os guardiães dos deuses. Símbolo da natureza humana e divina de Cristo.

Representações de grifos podem ser observadas na Igreja Matriz de Nossa Senhoras da Graça (Figura VII) e na Igreja Santa Madalena (Figura VIII). 


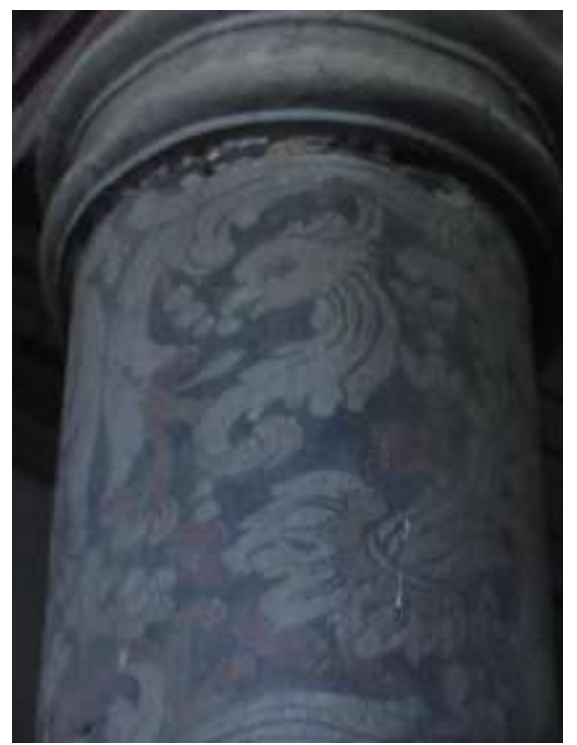

Figura VII - Colunas da Igreja Matriz de Nossa Senhora da Graça

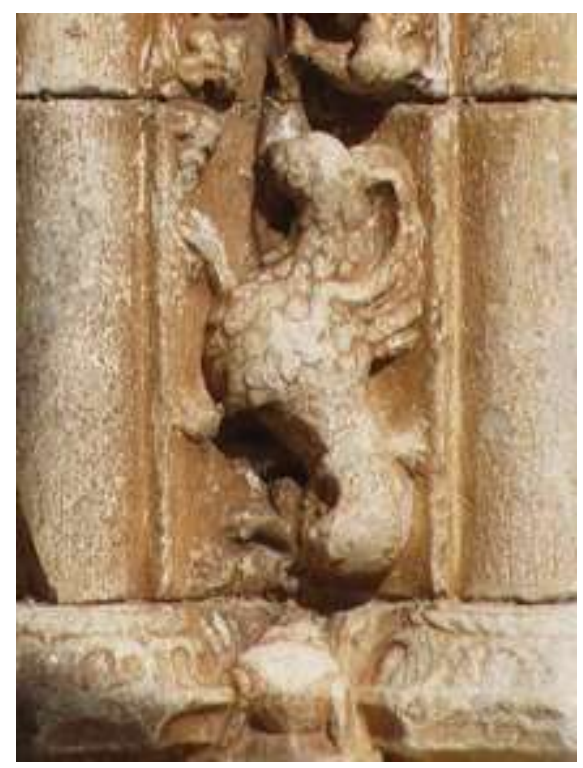

Figura VIII - Portal da Igreja Santa Madalena

HARPIAS - São criaturas monstruosas uma combinação do corpo de abutre e rosto feminino, com bico e garras, exalando um odor fétido. Destruidoras e vorazes, eram demónios alados implacáveis.

Os exemplares de harpias mais curiosos e interessantes, podem ser vistos na Igreja do Mosteiro de Santo Tirso (Figura IX) e na Igreja Matriz de Atouguia da Baleia (Figura X). 

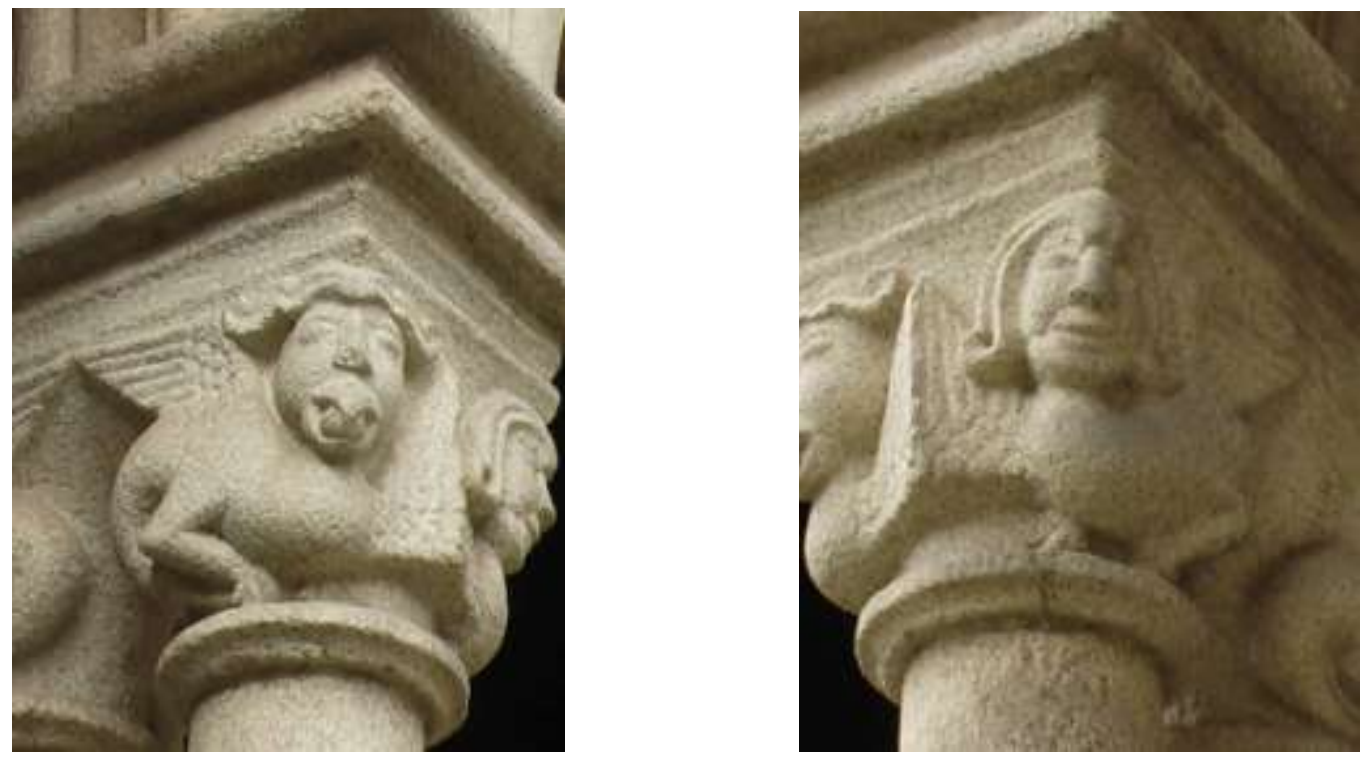

Figura IX - Claustro da Igreja do Mosteiro de Santo Tirso

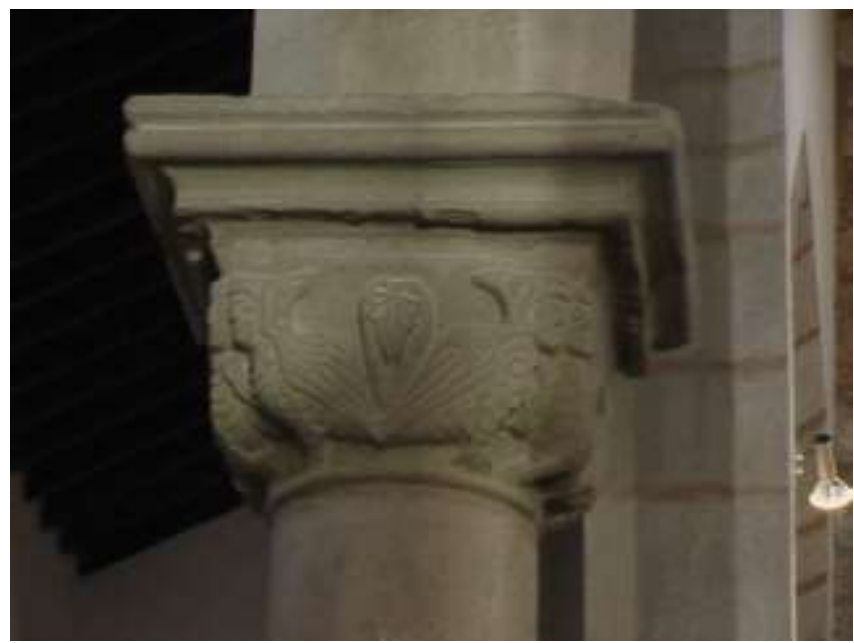

Figura X - Capitel da Igreja Matriz de Atouguia da Baleia

SEREIAS - O mito das sereias, presente em várias culturas, permanece fascinante. Representadas na época grega como mulheres pássaros, transfiguram-se na Idade Média em mulheres peixes. Criaturas híbridas, a sua mutação também provocou modificações na sua simbologia. Para o Cristianismo significavam pecado, vaidade e luxúria. Existem também algumas representações de sereias bífidas. 
As representações mais expressivas de sereias que encontrámos estão na Igreja do Mosteiro dos Lóios de Vilar de Frades (Figura XI) e na Igreja de Nossa Senhora da Assunção (Figura XII).

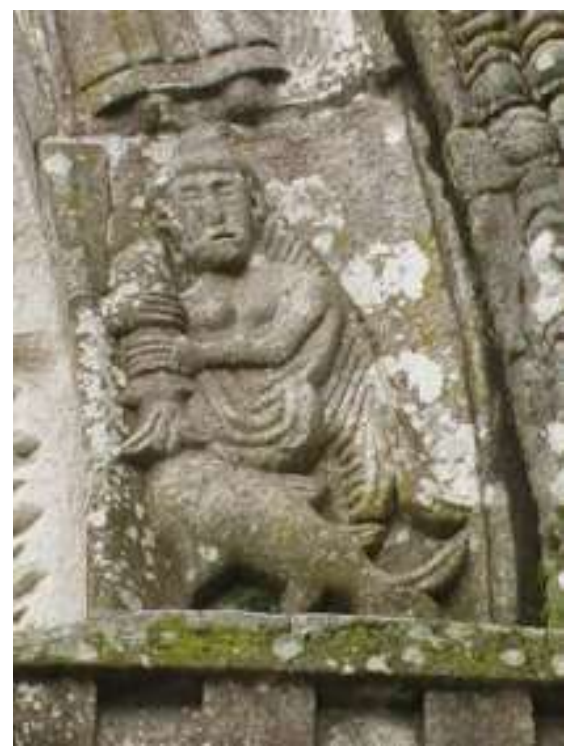

Figura XI - Arquivolta do Portal da Igreja do Mosteiro dos Lóios de Vilar de Frades

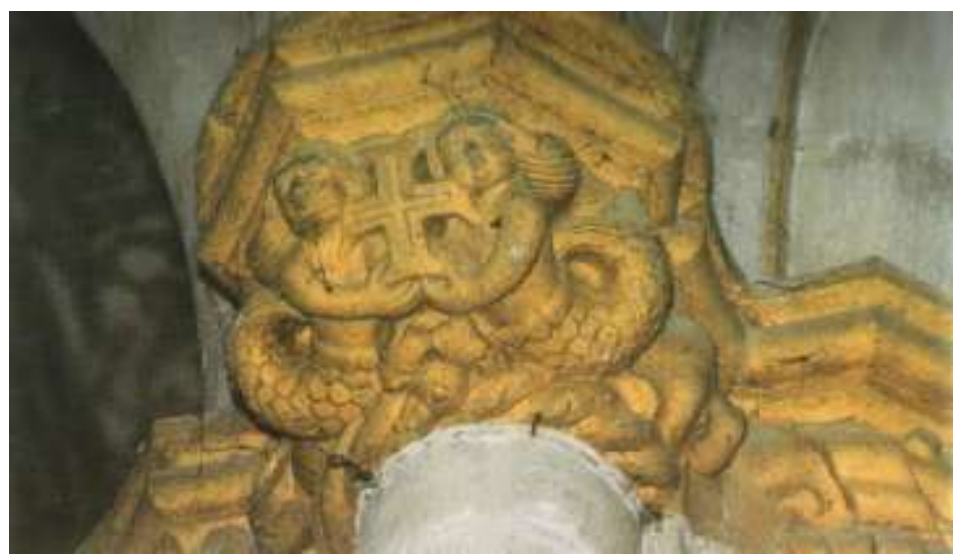

Figura XII - Capitel da Igreja de Nossa Senhora da Assunção

O animal sempre foi parte integrante da vida do homem, e na arte, em particular na escultura, a sua simbologia variou consoante a época, o local, o material utilizado, os valores culturais e as influências de outros povos.

Símbolos de virtudes e vícios, os animais fantásticos foram na Idade Média associados ao espaço cristão, ao templo. 
A Arte Românica foi a primeira com dimensão europeia e especialmente a escultura, reflectiu uma estreita relação com a literatura e as artes móveis.

O Românico Português teve uma expressão muito própria da nossa cultura e tradições.

Concluímos então que de facto os animais fantásticos mais representados no Românico Português são os dragões e as sereias.

Os dragões começaram por se símbolos de sabedoria e magia, mas o Cristianismo transformou-os numa encarnação do Mal, mantendo contudo sempre uma aura de mistério.

Símbolos do ar, do fogo, da água e da terra, são geralmente representados como grandes repteis, de corpo escamado, asas de pássaro, garras de águia, com chifres e cauda serpentinada, exalando fogo.

As sereias também oscilaram entre símbolos do Bem e do Mal. Representadas de início como seres alados surgem no Românico como mulheres-peixe, não se sabendo ao certo se a tradição oral transformou a sereia numa figura feminina sedutora, maléfica e perigosa ou se o ascetismo e a reforma gregoriana foi buscar a lenda da tradição oral e a tornou objecto de repulsa.

Também as harpias têm algum destaque, representadas frequentemente como criaturas monstruosas, significam as paixões obsessivas e o remorso inerente à satisfação das mesmas.

Conotadas com as energias cósmicas, sugerem a provocação dos vícios e maldades e só podem ser afugentadas pela força do espírito. A sua aparência é a de mulheres com corpo de abutre, rosto feminino, bico e unhas recurvas e segundo a lenda exalavam um odor fétido.

Foram a imagem dos ventos, das secas, fomes e epidemias. Imunes à ira dos deuses, eram forças brutais da natureza, pálidas e gélidas como o vento, destruidoras e vorazes, demónios alados implacáveis.

Por sua vez, representados em menor número surgem os centauros e os grifos. Os primeiro possuem também múltipla simbologia: sábios, guerreiros, mas também associados à luxúria e aos vícios em geral. 
Os grifos eram conotados com a natureza humana e divina de Cristo, leais e valentes, protegiam os lugares sagrados.

Todavia os animais fantásticos, na maioria das vezes, poderão ser produto da imaginação do homem medievo, mas o que é certo é que estes ultrapassaram os tempos, continuando a alimentar a nossa fantasia até hoje.

\begin{tabular}{|c|c|c|c|}
\hline Tema & Nome & Localização & Suporte \\
\hline \multirow{5}{*}{ A Árvore da Vida } & $\begin{array}{l}\text { Igreja de S.Cristovão } \\
\text { de Rio Mau }\end{array}$ & Portal Norte & Tímpano \\
\hline & $\begin{array}{l}\text { Capela de Nossa } \\
\text { Senhora da Orada }\end{array}$ & Portal Norte & Tímpano \\
\hline & $\begin{array}{l}\text { Igreja de S. Pedro } \\
\text { de Bravães }\end{array}$ & Portal Sul & Tímpano \\
\hline & $\begin{array}{l}\text { Igreja S. Martinho } \\
\text { de Cedofeita }\end{array}$ & Portal Principal & Capitéis \\
\hline & $\begin{array}{l}\text { Igreja Matriz de Alvor, } \\
\text { Igreja do Divino } \\
\text { Salvador de Alvor } \\
\text { (Portimão) }\end{array}$ & Portal Principal & $\begin{array}{l}\text { Colunas e } \\
\text { Arquivoltas }\end{array}$ \\
\hline Tema & Nome & Localização & Suporte \\
\hline \multirow{2}{*}{ Os Dragões } & $\begin{array}{l}\text { Igreja S. Martinho } \\
\text { de Cedofeita }\end{array}$ & Portal Principal & Capitéis \\
\hline & $\begin{array}{l}\text { Igreja Matriz de Autogia } \\
\text { da Baleia (S. Leonardo) }\end{array}$ & Portal Principal & Capitéis \\
\hline
\end{tabular}




\begin{tabular}{|c|c|c|c|}
\hline & $\begin{array}{l}\text { Convento do Mosteiro de } \\
\text { Santa Cruz de Celas }\end{array}$ & Claustro & Capitel Duplo \\
\hline & Mosteiro Alcobaça & Claustro & Capitéis \\
\hline & $\begin{array}{l}\text { Convento Nossa Senhora } \\
\text { da Conceição (Beja) }\end{array}$ & Interior & $\begin{array}{l}\text { Portal Sala } \\
\text { Capítulo }\end{array}$ \\
\hline & $\begin{array}{l}\text { Igreja de Nossa Senhora } \\
\text { da Graça } \\
\text { (Moncarapacho, Olhão) }\end{array}$ & Interior & $\begin{array}{l}\text { Capela do } \\
\text { Calvário: } \\
\text { Capitéis }\end{array}$ \\
\hline & Igreja Matriz da Golegã & Portal Principal & Colunas \\
\hline & $\begin{array}{l}\text { Convento do Mosteiro } \\
\text { dos Loios, Igreja de } \\
\text { Nossa Senhora da } \\
\text { Assunção (Arraiolos) }\end{array}$ & Portal Principal & \\
\hline & Palácio de D. Manuel & Janela & \\
\hline Tema & Nome & Localização & Suporte \\
\hline O Centauro & $\begin{array}{l}\text { Igreja de S.Cristovão } \\
\text { de Rio Mau }\end{array}$ & Portal Norte & Coluna \\
\hline
\end{tabular}

\begin{tabular}{|l|l|l|l|}
\hline Tema & Nome & Localização & Suporte \\
\hline \multirow{4}{*}{ Os Grifos } & $\begin{array}{l}\text { Igreja de Nossa Senhora } \\
\text { da Graça } \\
\text { (Moncarapacho, Olhão) }\end{array}$ & Interior & Coluna \\
\cline { 2 - 4 } & $\begin{array}{l}\text { Igreja Santa } \\
\text { Madalena (Olivença })\end{array}$ & Portal Sul & Colunas \\
\hline As Harpias & $\begin{array}{l}\text { Igreja do Mosteiro de } \\
\text { S. Bento de Santo Tirso }\end{array}$ & Claustro & Colunas/Pilastras \\
\hline
\end{tabular}




\begin{tabular}{|c|c|c|c|}
\hline & $\begin{array}{l}\text { Igreja Matriz de Autogia } \\
\text { da Baleia (S. Leonardo) }\end{array}$ & Interior & $\begin{array}{l}\text { Capitel Nave } \\
\text { Lateral Esquerda } \\
\text { e Central }\end{array}$ \\
\hline & \multirow{2}{*}{ Sé Lisboa } & Portal Principal & Capitel \\
\hline & & Claustro & Capitel \\
\hline Tema & Nome & Localização & Suporte \\
\hline \multirow{7}{*}{ As Sereias } & $\begin{array}{l}\text { Igreja de S. Pedro } \\
\text { de Rates }\end{array}$ & Portal Principal & Capitel \\
\hline & $\begin{array}{l}\text { Igreja do Mosteiro } \\
\text { dos Lóios de Vilar de } \\
\text { Frades }\end{array}$ & Portal Antigo & $2^{\mathrm{a}}$ Arquivolta \\
\hline & Sé Braga & Portal Principal & Arquivolta \\
\hline & & Portal Principal & Tímpano \\
\hline & & Portal Norte & Capitéis \\
\hline & $\begin{array}{l}\text { Igreja de Almacave } \\
\text { (Lamego) }\end{array}$ & Portal Principal & Capitel \\
\hline & $\begin{array}{l}\text { Igreja de Nossa Senhora } \\
\text { da Assunção (Elvas) }\end{array}$ & Interior & Mísula e Capitel \\
\hline
\end{tabular}




\section{COMO CITAR ESTE ARTIGO}

\section{Referência electrónica:}

MARQUES, Marisa Costa - O Mundo do Fantástico na Arte Românica e Gótica em Portugal. O género diplomático 'notícia' na documentação medieval portuguesa (séculos X-XIII). Tese de Mestrado em História da Arte, apresentada à Faculdade de Ciências Sociais e Humanas da Universidade Nova de Lisboa em Julho de 2007. Medievalista [Em linha]. No8, (Julho de 2010). [Consultado dd.mm.aaaa]. Disponível em http://www2.fcsh.unl.pt/iem/medievalista/MEDIEVALISTA81marques8013.html. ISSN 1646-740X.

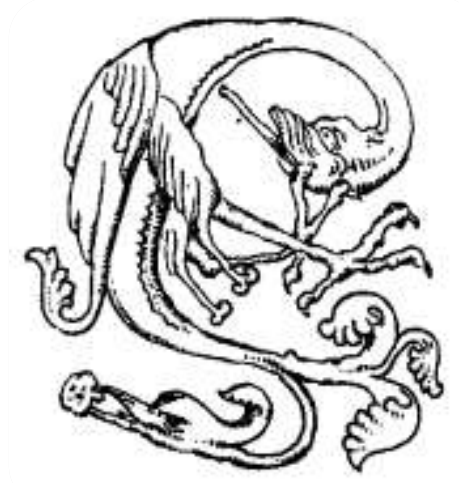

